\title{
EFEKTIVITAS MODEL PEMBELAJARAN KOOPERATIF TIPE STAD DAN TGT TERHADAP HASIL BELAJAR MATEMATIKA SISWA KELAS VIII SMPN 05 BATAM
}

\author{
Abdul Aziz , Yessy Yusnita \\ Program Studi Pendidikan Matematika, Fakultas Keguruan dan Ilmu Pendidikan \\ Universitas Riau Kepulauan, Batam, Kepulauan Riau, Indonesia \\ Email: "abdulaziz160891@gmail.com
}

\begin{abstract}
Abstrak. Penelitian ini bertujuan untuk mengetahui efektivitas model pembelajaran kooperatif tipe STAD dan TGT terhadap hasil belajar matematika. Penelitian ini menggunakan metode kuantitatif dengan jenis penelitian komparasi. Populasi dalam penelitian ini adalah seluruh siswa SMPN 05 Batam Kelas VIII tahun pelajaran 2016/2017. Sampel penelitian sebanyak 60 siswa. Pengambilan Sampel dilakukan dengan teknik sampling jenuh. Sampel dalam penelitian ini sebanyak dua kelas yaitu kelas eksperimen I sebagai kelas eksperimen STAD dan kelas eksperimen II sebagai kelas eksperimen TGT. Teknik analisis data terdiri dari uji prasyarat menggunakan rumus chi kuadrat dan uji $\mathrm{F}$, uji keseimbangan dengan menggunakan rumus uji-t dua sampel dengan polled varians dan uji hipotesis dengan menggunakan uji-t satu sampel dan uji-t dua sampel dengan separated varians. Hasil perhitungan uji hipotesis 1 diperoleh nilai $t_{\text {hitung }}=3,89$ ternyata $t_{\text {hitung }}>t_{\text {tabel }}$ maka $\mathrm{H}_{\mathrm{a}}$ diterima artinya model pembelajaran kooperatif tipe STAD efektif dalam meningkatkan hasil belajar matematika siswa. Hasil perhitungan uji hipotesis 2 diperoleh nilai $t_{\text {hitung }}=0,58$ ternyata $t_{\text {hitung }} \leq t_{\text {tabel }}$ maka $H_{0}$ diterima artinya model pembelajaran kooperatif tipe TGT tidak efektif dalam meningkatkan hasil belajar matematika siswa. Hasil perhitungan uji hipotesis 3 diperoleh nilai $t_{\text {hitung }}=2,24$ ternyata $t_{\text {hitung }}>$ $t_{\text {tabel }}$ maka $\mathrm{H}_{\mathrm{a}}$ diterima. Dapat disimpulkan terdapat perbedaan keefektifan model pembelajaran kooperatif tipe STAD dan TGT terhadap hasil belajar matematika.
\end{abstract}

Kata kunci: Pembelajaran Kooperatif, STAD, TGT, Hasil Belajar Matematika

Abstract. The purpose of this study was to know the effectiveness of cooperative learning model STAD and TGT types toward the student's learning result. This study was carried out by implementing quantitative research method using comparative approach. The population in this research is all of eight grades students in SMPN 05 Batam academic year 2016/2017. Sample of this research is 60 students. This sample is taken by using saturated sampling technique. Sample of this research are two classes those are experiment's class I as experiment STAD's class and experiment's class II as experiment TGT's class. Data analysis technique consists of precondition test that includes normality test using chi kuadrat formula and homogeneity test using F test formula. It's continued with balance test using t-test two samples with polled variants and hypothesis test using t-test one sample and t-test two samples with separated variants. The result of testing the hypothesis 1 was obtained that the score of $t_{\text {count }}=3,89$ that $t_{\text {count }}>t_{\text {table }}$ so $H_{a}$ accepted. It means that the cooperative learning model STAD type is effective to increases the student's math learning result. The result of testing the hypothesis 2 was obtained that the score of $t_{\text {count }}=0,58$ that $t_{\text {count }} \leq t_{\text {table }}$ so $\mathrm{H}_{0}$ accepted. It means that cooperative learning model TGT type isn't effective to increases student's math learning result. The result of testing the hypothesis 3 was obtained that the score of $t_{\text {count }}=2,24$ that $t_{\text {count }}>t_{\text {table }}$ so $H_{a}$ accepted. It can be concluded that there is difference of effectiveness cooperative learning model STAD and TGT types toward the math learning result.

Key words: Cooperative Learning, STAD, TGT, Math Learning Result.

\section{Pendahuluan}

Pendidikan adalah hal yang penting bagi setiap orang. Pendidikan pada dasarnya dianggap dapat menjamin seseorang untuk berhasil di masa depan. Setiap orang berlombalomba untuk mendapatkan jenjang pendidikan yang tinggi, dengan harapan akan mendapat 
kesuksesan di masa yang akan datang. Pendidikan dapat ditempuh secara formal dan informal, secara formal pendidikan didapat di lingkungan sekolah. Dalam lingkungan sekolah pendidikan dipengaruhi beberapa unsur, salah satunya yaitu guru sebagai tenaga pendidik dan siswa sebagai peserta didik. Antara guru dan siswa pada setiap harinya terjadi interaksi yang menunjukkan adanya kegiatan belajar mengajar atau proses pembelajaran.

Berdasarkan wawancara peneliti dengan salah satu guru matematika di SMPN 05 Batam, diperoleh informasi pada umumnya kegiatan pembelajaran matematika di kelas dimulai dari guru yang menjelaskan materi pelajaran di depan kelas, lalu dilanjutkan dengan pembagian kelompok belajar yang terdiri dari 4-6 orang siswa yang heterogen. Setelah kelompok belajar terbentuk guru membagikan Lembar Kerja Siswa (LKS). Namun pada proses pembelajaran matematika berlangsung, siswa yang aktif hanya siswa yang pintar saja, sedangkan siswa yang kurang pintar lebih memilih mengobrol dengan siswa lainnya. Keberanian siswa untuk bertanya kepada guru masih sangat kurang, sehingga interaksi timbal balik antara siswa dengan guru masih kurang dirasakan dan siswa terkesan pasif. Permasalahan lain yang terjadi dalam pembelajaran matematika adalah hasil belajar siswa yang masih rendah. Berdasarkan daftar nilai pelajaran matematika dari guru bidang studi matematika di SMPN 05 Batam diperoleh informasi bahwa nilai rata-rata ulangan harian matematika siswa kelas VIII semester ganjil di SMPN 05 Batam masih banyak yang belum mencapai Kriteria Ketuntasan Minimal (KKM) yang ditetapkan sekolah yaitu sebesar 71 untuk setiap materi pokok, seperti yang tertera pada tabel 1.

Tabel 1. Nilai Rata-Rata Ulangan Harian Matematika Kelas VIII Semester Ganjil Tahun Pelajaran 2016/2017

\begin{tabular}{cccccccc}
\hline No & Kelas & $\begin{array}{c}\text { Jumlah } \\
\text { siswa }\end{array}$ & KKM & $\begin{array}{c}\text { Banyak siswa } \\
\text { memenuhi } \\
\text { KKM }\end{array}$ & $\begin{array}{c}\text { Banyak siswa } \\
\text { dibawah KKM }\end{array}$ & $\begin{array}{c}\text { Persen } \\
\text { ketuntasan }\end{array}$ & $\begin{array}{c}\text { Persen } \\
\text { ketidak } \\
\text { tuntasan }\end{array}$ \\
\hline 1 & VIIIA & 30 & 71 & 11 & 19 & $37 \%$ & $63 \%$ \\
2 & VIIIB & 30 & 71 & 10 & 20 & $33 \%$ & $67 \%$ \\
\hline & Total & 60 & & 21 & 39 & $35 \%$ & $65 \%$ \\
\hline
\end{tabular}

Sumber: Guru Matematika SMPN 05 Batam

Berdasarkan tabel 1, dari keseluruhan siswa kelas VIII yang ada di SMPN 05 Batam dapat dilihat bahwa 35\% siswa memenuhi kriteria ketuntasan minimal, dan masih ada $65 \%$ siswa yang belum tuntas mencapai nilai KKM. Hal ini membuktikan bahwa hasil belajar matematika di kelas VIII SMPN 05 Batam perlu ditingkatkan lagi, ketidaktuntasan hasil belajar matematika salah satunya disebabkan sebagian besar siswa masih mengalami kesulitan dalam memahami mata pelajaran matematika. Kesulitan siswa dalam mempelajari matematika disebabkan oleh beberapa hal, dari siswa itu sendiri atau dari guru sebagai tenaga pendidik. Kesulitan belajar matematika yang dialami siswa yang disebabkan oleh guru sebagai tenaga pendidik dikarenakan guru selama ini masih menggunakan model pembelajaran konvensional dalam mengajar, guru hanya menerangkan dan siswa sebagai pendengar yang baik. Siswa hanya disuruh mendengarkan penjelasan guru, mencatat, lalu mengerjakan latihan. Hal ini menyebabkan pembelajaran menjadi tidak efektif dimana siswa 
tidak terlibat langsung dalam kegiatan belajar dan cenderung pasif terhadap proses pembelajaran di kelas.

Berkenaan dengan hal ini perlu adanya pembelajaran yang bervariasi dan dapat merangsang serta melibatkan siswa aktif, baik secara fisik, intelektual maupun emosional. Bentuk pembelajaran yang dapat melibatkan siswa secara aktif adalah bentuk pembelajaran kooperatif. Pada model pembelajaran kooperatif siswa diberi kesempatan untuk berkomunikasi dan berinterakasi sosial dengan temannya untuk mencapai tujuan pembelajaran, sementara guru bertindak sebagai motivator dan fasilitator aktifitas siswa. Artinya dalam pembelajaran ini kegiatan aktif dengan pengetahuan dibangun sendiri oleh siswa dan mereka bertanggung jawab atas hasil pembelajarannya.

Dalam pembelajaran kooperatif, belajar dikatakan belum selesai jika salah satu teman dalam kelompok belum menguasai bahan pelajaran. Menurut Lie (Isjoni, 2007: 16) menyebutkan pembelajaran kooperatif dengan istilah pembelajaran gotong royong, yaitu sistem pembelajaran yang memberi kesempatan pada peserta didik untuk bekerja sama dengan siswa lain dalam tugas-tugas terstruktur. Lebih jauh lagi dikatakan, pembelajaran kooperatif hanya berjalan kalau sudah terbentuk suatu kelompok atau suatu tim yang didalamnya siswa bekerja secara terarah untuk mencapai tujuan yang sudah ditentukan dengan jumlah anggota kelompok pada umumnya terdiri atas 4-6 orang saja.

Menurut Isjoni (2007: 20) beberapa ciri dari pembelajaran kooperatif adalah; (a) setiap anggota memiliki peran, (b) terjadi hubungan interaksi langsung diantara siswa, (c) setiap anggota kelompok bertanggung jawab atas belajarnya dan juga teman-teman sekelompoknya, (d) guru membantu mengembangkan keterampilan-keterampilan interpersonal kelompok dan, (e) guru hanya berinteraksi dengan kelompok saat diperlukan. Menurut Macmilan (dalam Isjoni, 2007: 23) pembelajaran kooperatif memiliki beberapa keunggulan. Keunggulannya dilihat dari aspek siswa adalah memberi peluang kepada siswa agar mengemukakan dan membahas suatu pandangan, pengalaman yang diperoleh siswa belajar secara bekerja sama dalam merumuskan kearah satu pandangan kelompok. Selanjutnya Isjoni (2007: 23) menyatakan bahwa model pembelajaran ini memungkinkan siswa untuk mengembangkan pengetahuan, kemampuan dan keterampilan secara penuh dalam suasana belajar terbuka dan demokrasi. Siswa bukan lagi sebagai objek pembelajaran, namun bisa juga berperan sebagai tutor bagi teman sebayanya.

Model pembelajaran kooperatif tipe Student Teams Achievement Division (STAD) dikembangkan oleh Robert Slavin yang merupakan salah satu bagian dari pembelajaran kooperatif yang paling sederhana pelaksanaannya. Model pembelajaran kooperatif tipe STAD mengacu pada pembelajaran secara berkelompok dengan jumlah anggota 4-5 orang siswa dengan syarat kelompok yang terbentuk haruslah bersifat heterogen artinya: terdiri dari lakilaki dan perempuan, dari berbagai suku, memiliki kemampuan tinggi, sedang, dan rendah, serta harus memperhatikan status sosial ekonomi dari setiap anggota kelompok yang sudah terbentuk. Adanya model pembelajaran ini akan meningkatkan kerjasama diantara anggota kelompok, dan mereka bisa saling berbagi pengetahuan antara siswa yang pintar, sedang, dan kurang. Model pembelajaran kooperatif tipe Student Teams Achievement Division (STAD) 
terdiri atas lima komponen utama yaitu presentasi kelas, kerja kelompok (tim), kuis, skor kemajuan individual, rekognisi (penghargaan) kelompok.

Langkah-langkah penerapan pembelajaran kooperatif tipe STAD (Slavin, 2009) :

1. Guru menyampaikan materi pembelajaran atau permasalahan kepada siswa sesuai kompetensi dasar yang akan dicapai.

2. Guru memberikan tes/kuis kepada setiap siswa secara individual sehingga akan diperoleh skor awal.

3. Guru membentuk beberapa kelompok. Setiap kelompok terdiri dari 4-5 siswa dengan kemampuan yang berbeda-beda (tinggi, sedang dan rendah). Jika mungkin anggota kelompok berasal dari ras, budaya, suku yang berbeda.

4. Bahan materi yang telah dipersiapkan didiskusikan dalam kelompok untuk mencapai kompetensi dasar. Pembelajaran kooperatif tipe STAD, biasanya digunakan untuk penguatan pemahaman materi.

5. Guru memfasilitasi siswa dalam membuat rangkuman, mengarahkan, dan memberikan penegasan pada materi pembelajaran yang telah dipelajari.

6. Guru memberikan tes/kuis kepada setiap siswa secara individual.

7. Guru memberikan penghargaan pada kelompok berdasarkan perolehan nilai peningkatan hasil belajar individual dari skor dasar ke skor kuis berikutnya.

Model pembelajaran kooperatif tipe Teams Games Tournament (TGT), pada mulanya dikembangkan oleh David DeVries dan Keith Edwards. Dalam model ini, para siswa dibagi dalam tim belajar yang terdiri atas empat sampai lima orang yang berbeda-beda tingkat kemampuan, jenis kelamin, dan latar belakang etniknya. Guru menyampaikan pelajaran, lalu siswa bekerja dalam tim mereka untuk memastikan bahwa semua anggota tim telah menguasai pelajaran. Selanjutnya diadakan turnamen, dimana siswa memainkan game akademik dengan anggota tim lain untuk menyumbangkan poin bagi skor timnya. TGT menambahkan dimensi kegembiraan yang diperoleh dari penggunaan permainan. Teman satu tim akan saling membantu dalam mempersiapkan diri untuk permainan dengan mempelajari lembar kegiatan, menjelaskan masalah-masalah satu sama lain, dan memastikan telah terjadi tanggung jawab individual (Slavin, 2009). Pembelajaran kooperatif tipe TGT terdiri dari 5 komponen utama, yaitu : presentasi kelas, kerja kelompok (tim), games, turnamen, rekognisi (penghargaan) kelompok.

Menurut Slavin (2009: 163) secara umum model pembelajaran kooperatif tipe TGT sama saja dengan model pembelajaran kooperatif tipe STAD kecuali satu hal, yaitu model pembelajaran kooperatif tipe TGT menggunakan turnamen akademik, yakni menggunakan kuis-kuis dan skor kemajuan individu dimana siswa berlomba sebagai wakil dari kelompok mereka dengan anggota kelompok lain yang kinerja akademik sebelumnya setara seperti mereka.

\section{Metodologi Penelitian}

Penelitian ini termasuk dalam jenis penelitian komparasi atau perbandingan. Dengan membandingkan hasil belajar di kelas eksperimen 1 yang menggunakan model pembelajaran 
kooperatif tipe STAD dengan kelas eksperimen 2 yang menggunakan model pembelajaran kooperatif tipe TGT seperti pada tabel 2.

Tabel 2. Desain Penelitian Komparasi

\begin{tabular}{cccc}
\hline Sampel & Pretest & Perlakuan & Post test \\
\hline Kelas eksperimen 1 & $\mathrm{T}_{1}$ & $\mathrm{X}_{1}$ & $\mathrm{~T}_{2}$ \\
Kelas eksperimen 2 & $\mathrm{T}_{1}$ & $\mathrm{X}_{2}$ & $\mathrm{~T}_{2}$ \\
\hline
\end{tabular}

Modifikasi (Sugiyono, 2012)

Keterangan :

$\mathrm{T}_{1} \quad=$ tes awal (pre-test)

$\mathrm{T}_{2} \quad=$ tes akhir (post-test)

$\mathrm{X}_{1} \quad=$ perlakuan tipe $\mathrm{STAD}$

$\mathrm{X}_{2}=$ perlakuan tipe TGT

Populasi dalam penelitian ini adalah seluruh siswa kelas VIII SMP Negeri 05 Batam yang berjumlah 60 siswa. Teknik pengambilan sampel yang digunakan adalah sampling jenuh. Jumlah sampel yang diambil dalam penelitian ini yaitu siswa kelas VIII $^{\mathrm{A}}$ yang berjumlah 30 siswa sebagai kelas eksperimen STAD dan VIII $^{\mathrm{B}}$ yang berjumlah 30 orang sebagai kelas eksperimen TGT.

\section{Teknik Analisis Instrumen}

Untuk menguji validitas instrumen peneliti menggunakan rumus pearson product moment (Riduwan, 2005: 227) :

$$
\mathrm{r}_{\text {hitung }}=\frac{\mathrm{n} \sum x y-\left(\sum x\right)\left(\sum y\right)}{\sqrt{\left\{n \sum x^{2}-\left(\sum x\right)^{2}\right\} \cdot\left\{n \sum y^{2}-\left(\sum y\right)^{2}\right\}}}
$$

keterangan :

$\mathrm{r}_{\text {hitung }}=$ koefisien korelasi

$\mathrm{x}=$ skor item instrumen yang akan digunakan

$\mathrm{y}=$ skor semua item instrumen dalam variabel tersebut

$\Sigma \mathrm{x} \quad=$ jumlah skor item instrumen yang akan digunakan

$\Sigma \mathrm{y} \quad=$ jumlah skor semua item instrumen dalam variabel tersebut

$\mathrm{n} \quad=$ jumlah responden

Selanjutnya untuk menguji reliabilitas instrumen peneliti menggunakan rumus K-R.20, yaitu (Sugiyono, 2011: 359) :

$$
\mathrm{r}_{\mathrm{i}}=\left(\frac{k}{(k-1)}\right)\left\{1-\frac{S \mathrm{t}^{2}-\Sigma p_{i} q_{i}}{S \mathrm{t}^{2}}\right\}
$$

keterangan :

$\mathrm{r}_{\mathrm{i}}=$ nilai reliabelitas instrumen

$\mathrm{k}=$ jumlah item dalam instrumen 
$\mathrm{p}_{\mathrm{i}}=$ proporsi banyaknya subyek yang menjawab pada item 1

$\mathrm{q}_{\mathrm{i}}=1-\mathrm{p}_{\mathrm{i}}$

$\mathrm{s}_{\mathrm{t}}=$ varian total

\section{Teknik Analisis Data}

Uji normalitas dapat dilakukan dengan menggunakan rumus chi kuadrat $\left(\chi^{2}\right)$ (Sugiyono, 2011: 107).

$$
\begin{aligned}
& \quad \chi^{2}=\sum \frac{\left(\mathrm{f}_{0}-\mathrm{fh}\right)^{2}}{\mathrm{fh}} \\
& \text { keterangan : } \\
& \chi^{2}=\text { Chi Kuadrat } \\
& \mathrm{f}_{0}=\text { frekuensi yang diobservasi } \\
& \mathrm{f}_{0}=\text { frekuensi yang diharapkan }
\end{aligned}
$$

Untuk menguji homogenitas data peneliti menggunakan rumus Uji F (Sugiyono, 2011: 140), yaitu:

$$
\mathrm{F}_{\text {hitung }}=\frac{\text { varian terbesar }}{\text { varian terkecil }}
$$

dengan rumus varian (Sugiyono 2011: 57):

$$
\mathrm{S}^{2}=\frac{\Sigma(X i-\bar{X})^{2}}{(n-1)}
$$

Keterangan :

$S^{2}=$ varian sampel

$\overline{\mathrm{X}}=$ nilai rata-rata sampel

$\mathrm{X}_{\mathrm{i}}=$ nilai sampel

$\mathrm{n}=$ jumlah sampel

Untuk uji hipotesis 1 dan 2 peneliti menggunakan rumus one sample t-test (Sugiyono, 2011: 96).

$$
t_{\text {hitung }}=\frac{\overline{\mathrm{X}}-\mu_{0}}{\frac{s}{\sqrt{n}}}
$$

keterangan :

$\overline{\mathrm{X}}=$ rata-rata $\mathrm{x}_{1}$

$\mu_{0}=$ nilai yang dihipotesiskan sesuai dengan nilai KKM yang sudah ditetapkan sekolah yaitu 71

$\mathrm{s}=$ simpangan baku

$\mathrm{n}=$ jumlah anggota sampel

Selanjutnya untuk menguji hipotesis 3 peneliti menggunakan rumus independent sample $t$-test atau $t$-test separated varians (Sugiyono 2011: 138).

$$
\mathrm{t}_{\text {hitung }}=\frac{\overline{\mathrm{X}}_{1}-\overline{\mathrm{X}}_{2}}{\sqrt{\frac{s_{1}{ }^{2}}{n_{1}}+\frac{s_{2}{ }^{2}}{n_{2}}}}
$$


keterangan :

$\overline{\mathrm{X}}_{1}=$ nilai rata-rata post-test kelas eksperimen 1

$\overline{\mathrm{X}}_{2}=$ nilai rata-rata post-test kelas eksperimen 2

$\mathrm{n}_{1}=$ banyaknya data kelas eksperimen 1

$\mathrm{n}_{2}=$ banyaknya data kelas eksperimen 2

$\mathrm{S}_{1}{ }^{2}=$ varians data kelas eksperimen 1

$\mathrm{S}_{2}{ }^{2}=$ varians data kelas eksperimen 2

\section{Hasil Penelitian Dan Pembahasan}

Berdasarkan hasil penelitian peneliti dengan menggunakan model pembelajaran kooperatif tipe STAD dan TGT. Dapat disimpulkan bahwa model pembelajaran kooperatif tipe STAD lebih efektif dibandingkan model pembelajaran kooperatif tipe TGT, hal ini terlihat dari data hasil belajar siswa bahwa nilai rata-rata kelas eksperimen STAD adalah 79,33 dan nilai rata-rata kelas eksperimen TGT adalah 72,33. Persentase ketuntasan belajar siswa kelas eksperimen STAD sebesar 63,33\% lebih tinggi dari persentase ketuntasan belajar siswa kelas eksperimen TGT sebesar 46,67\%. Hasil belajar pada kelas eksperimen STAD dan kelas eksperimen TGT dapat dilihat pada tabel berikut:

Tabel 3. Hasil Belajar Kelas Eksperimen STAD dan TGT

\begin{tabular}{lccc}
\hline \multicolumn{1}{c}{ Kelas } & $\mathrm{N}$ & Jumlah siswa yang tuntas & Persentase ketuntasan \\
\hline Eksperimen STAD & 30 siswa & 19 siswa & $63,33 \%$ \\
Eksperimen TGT & 30 siswa & 14 siswa & $46,67 \%$ \\
\hline
\end{tabular}

Berdasarkan rekapitulasi hasil perhitungan uji normalitas, untuk kelas eksperimen STAD diperoleh nilai $\chi^{2}$ hitung sebesar 28,90 pada taraf 0,05 diperoleh nilai $\chi_{\text {tabel }}^{2}$ sebesar 43,773 sehingga $\chi_{\text {hitung }}^{2}<\chi_{\text {tabel }}^{2}$ maka data berdistribusi normal. Sedangkan untuk kelas eksperimen TGT diperoleh nilai $\chi^{2}$ hitung sebesar 38,15 pada taraf 0,05 diperoleh nilai $\chi^{2}$ tabel sebesar 43,773 sehingga $\chi_{\text {hitung }}^{2}<\chi_{\text {tabel }}^{2}$ maka data berdistribusi normal.

Berdasarkan hasil uji homogenitas diperoleh harga $F_{\text {hitung }}=1$,14. Harga $F_{\text {hitung }}$ ini dibandingkan dengan harga $\mathrm{F}_{\text {tabel }}$ dengan dk pembilang $\mathrm{n}-1=30-1=29$ dan dk penyebut $n$ $-1=30-1=29$. Karena nilai $\mathrm{F}_{\text {tabel }}$ dengan $\mathrm{dk}$ pembilang $=29$ dan dk penyebut $=29$ tidak ada pada tabel $\mathrm{F}$ maka peneliti mencari nilai $\mathrm{F}_{\text {tabel }}$ dengan bantuan Microsoft Excel dengan mengetik $=F I N V(0.05,29,29)$, maka harga $F_{\text {tabel }}$ untuk taraf signifikan $(\alpha)=5 \%$ adalah 1,86 . Ternyata harga $F_{\text {hitung }}<\mathrm{F}_{\text {tabel }}$ sehingga dapat disimpulkan bahwa data homogen dan perhitungan dapat dilanjutkan.

Dari perhitungan uji hipotesis 1 diperoleh $t_{\text {hitung }}=3,89$ dengan taraf signifikan adalah $5 \%$ dan $\mathrm{dk}=30-1=29$. Berdasarkan perhitungan tersebut diperoleh $\mathrm{t}_{\text {tabel }}=2,042$. Dengan demikian dapat disimpulkan bahwa $t_{\text {hitung }}=3,89>t_{\text {tabel }}=2,042$ maka Ha diterima dan Ho ditolak. Jadi kesimpulannya adalah model pembelajaran kooperatif tipe STAD efektif dalam meningkatkan hasil belajar matematika siswa. Sedangkan pada uji hipotesis 2 diperoleh $t_{\text {hitung }}$ $=0,58$ dengan taraf signifikan adalah $5 \%$ dan $\mathrm{dk}=30-1=29$. Berdasarkan perhitungan 
tersebut diperoleh $t_{\text {tabel }}=2,042$. dengan demikian dapat disimpulkan bahwa $t_{\text {hitung }}=0,58<$ $\mathrm{t}_{\text {tabel }}=2,042$ maka Ha ditolak dan Ho diterima. Jadi kesimpulannya adalah model pembelajaran kooperatif tipe TGT tidak efektif dalam meningkatkan hasil belajar matematika siswa. Sedangkan pada uji hipotesis 3 berdasarkan hasil perhitungan diperoleh $t_{\text {hitung }}=2,24$ dan pada $\mathrm{dk}=\mathrm{n}_{1}+\mathrm{n}_{2}-2=30+30-2=58$ dengan taraf signifikan $(\alpha)=0,05$ diperoleh $\mathrm{t}_{\text {tabel }}$ $=2,002$. dengan demikian dapat disimpulkan bahwa $t_{\text {hitung }}=2,24>\mathrm{t}$ tabel $=2,002$ maka Ha diterima dan Ho ditolak. Jadi kesimpulannya adalah terdapat perbedaan keefektifan model pembelajaran kooperatif tipe STAD dan TGT terhadap hasil belajar matematika siswa.

Dari hasil perhitungan di atas terbukti hasil belajar yang menggunakan model pembelajaran kooperatif tipe STAD lebih baik daripada hasil belajar yang menggunakan model pembelajaran kooperatif tipe TGT. Hal ini disebabkan dalam pembelajaran kooperatif tipe STAD siswa lebih bertanggungjawab dalam memahami pelajaran dan siswa juga bertanggung jawab terhadap hasil belajarnya baik untuk dirinya sendiri maupun untuk kelompoknya ini yang menyebabkan mereka akan berusaha semaksimal mungkin untuk memberikan yang terbaik baik untuk dirinya sendiri maupun kelompoknya. Dalam model pembelajaran kooperatif tipe STAD siswa akan saling membantu sesama anggota kelompoknya dalam memahami materi pembelajaran tersebut. Sehingga kekompakan dan kesungguhan siswa akan memberikan hasil yang terbaik bagi kelompoknya.

Selain itu dalam pembelajaran STAD pada saat guru memberikan tes tertulis sebagai bahan evaluasi belajar, waktu yang digunakan cukup efisien untuk setiap siswa sebagai anggota kelompok dalam menjawab soal-soal tersebut. Sedangkan pada model pembelajaran kooperatif tipe TGT siswa sudah diberikan kesempatan belajar secara berkelompok dan saling membantu memahami materi bersama-sama dengan anggota kelompoknya, namun pada saat evaluasi hasil belajar dimana guru memberikan turnamen kepada setiap anggota kelompok keadaan di kelas menjadi gaduh dan proses pembelajaran menjadi kurang efektif dan pada saat pelaksanaan turnamen siswa membutuhkan waktu yang cukup lama dalam menyelesaikan turnamen tersebut sehingga waktu yang digunakan menjadi tidak efisien. Hal inilah yang menyebabkan hasil belajar siswa yang menggunakan model pembelajaran kooperatif tipe TGT lebih rendah dibandingkan hasil belajar yang menggunakan model pembelajaran kooperatif tipe STAD.

\section{Kesimpulan}

Berdasarkan penelitian yang telah dilaksanakan, maka peneliti menarik kesimpulan sebagai berikut:

1. Penggunaan model pembelajaran kooperatif tipe STAD efektif dalam meningkatkan hasil belajar matematika siswa kelas VIII SMPN 05 Batam Tahun Pelajaran 2016/2017.

2. Penggunaan model pembelajaran kooperatif tipe TGT tidak efektif dalam meningkatkan hasil belajar matematika siswa kelas VIII SMPN 05 Batam Tahun Pelajaran 2016/2017.

3. Terdapat perbedaan keefektifan model pembelajaran kooperatif tipe STAD dan TGT dalam meningkatkan hasil belajar matematika siswa kelas VIII SMPN 05 Batam Tahun Pelajaran 2016/2017. 


\section{Daftar Pustaka}

Isjoni. (2007). Cooperative Learning Efektifitas Pembelajaran Kelompok. Bandung: Alfabeta.

Riduwan. (2011). Dasar-Dasar Statistik. Bandung: Alfabeta.

Slavin, Robert E. (2009). Cooperative Learning Teori, Riset dan Praktik. Bandung: Nusa Media.

Sugiyono. (2011). Statistika untuk Penelitian. Bandung: Alfabeta. 